\title{
ALTITUDINAL OCCURRENCE OF NON-NATIVE PLANT SPECIES (NEOPHYTES) AND THEIR HABITAT AFFINITY TO ANTHROPOGENIC BIOTOPES IN CONDITIONS OF SOUTH-WESTERN SLOVAKIA
}

\author{
MICHAL BENIAK ${ }^{1}, \check{Z ̆ A N E T A ~ P A U K O V A ́}^{2}$, ALEXANDER FEHÉR ${ }^{1}$ \\ ${ }^{1}$ Department of Sustainable Development, Slovak University of Agriculture in Nitra, Mariánska 10, 94901 Nitra, \\ Slovak Republic; e-mail: beniak.michal@gmail.com \\ ${ }^{2}$ Department of Ecology, Slovak University of Agriculture in Nitra, Mariánska 10, 94901 Nitra, Slovak Republic
}

\begin{abstract}
Beniak M., Pauková Ž., Fehér A.: Altitudinal occurrence of non-native plant species (neophytes) and their habitat affinity to anthropogenic biotopes in conditions of South-Western Slovakia. Ekológia (Bratislava), Vol. 34, No. 2, p. 163-175, 2015.

Many ecological studies showed that species density (the number of species per unit area) in nonnative organism groups of the mountain areas decreases with increasing altitude. The aim of the paper is to determine the variability in the incidence of non-native plant species (neophytes) associated with the change in altitude and links of the invading taxons to reference habitat types, as well as their links to three ecologically very similar, however in natural conditions, different areas. In general, the most invaded habitats are those which are highly influenced by human activities. Firstly, data collection was conducted through field mapping of build-up areas in South-western Slovakia. Subsequently, with the assistance of ordination methods, we evaluated the level of association of invasive neophytes according to the set objectives. We found that altitude was an important factor determining variability of invasive neophytes' occurrence. Total amount of habitats with invasive neophytes' occurrence showed a linear increase along the altitudinal gradient. Many invasive neophytes adapted to abandoned habitats of upland territory were also able to grow along roads, and vice versa, abandoned and unused habitats of lowland areas created conditions for many typical invasive neophytes occurring along roads and habitats of gardens and yards. Railways of lowland areas provided habitats and means of spread of invasive woody neophytes. Gardens and yards were important sources of alien neophytes in all observed territories. Invasive neophyte Aster novi-belgii can be described as a very variable species tolerant to a wide range of factors limiting the spread of species along the elevation gradient.
\end{abstract}

Key words: altitudinal occurrence, anthropogenic biotope, habitat affinity, invasive neophytes, South-Western Slovakia.

\section{Introduction}

Many ecological studies showed that species density (the number of species per unit area) in non-native organism groups of the mountain areas decreases with increasing altitude, or the number of non-native species slightly increase from lowlands to middle altitudes and 
decrease rapidly towards the high altitudes (Pauchard, Alaback, 2004; Arévalo et al., 2005; Becker et al., 2005; McDougall et al., 2005; Parks et al., 2005). Numbers of non-native species decrease with altitude more rapidly than numbers of native species and therefore lowlands are predominantly strongly invaded, while mountain areas have only a few non-native species (Chytrý, Pyšek, 2008).

In temperate areas, increasing altitude is associated with deteriorating conditions for plant growth such as decreases in the length of the growing season coupled with increasing frost and UV exposure (Körner, 2003). Also the low propagule pressure, biotic resistance from native species and a lack of adaptation to climatic conditions might constrain plant invasions along the gradient (Becker et al., 2005). Representation of different types of landscape structures, their spatial relations (distribution, interconnection or isolation etc.), but also changes in the structure of the landscape and landscape potential, can significantly affect speed of the spread and successful invasion of alien species in the area. Landscape structures in the area can facilitate (dense river, rail and road network, the predominance of deforested areas etc.) or impede (massive mountain ranges, large bodies of water, contiguous area of undisturbed original vegetation etc.) the spread of invasive species (Eliáš, 2001).

The causes of lower invasion level of foothill territory compared with lowland territory are not quite clear. This phenomenon is, to a great extent, caused by lower density of human population and lower intensity of traffic in the mountains. Therefore, the introduction of alien propagules causes a decline in occurrence of non-native species towards higher altitudes. Historical data also show that the lowlands were populated more often and more densely (Chytrý, Pyšek, 2008).

Human settlements provide environmental conditions that allow many of the imported non-native species to become established (McKinney, 2006). In general, the most invaded habitats are those that are highly influenced by human activities. A higher percentage of alien neophytes were found in human-made habitats (Deutschewitz et al., 2003; Lososová et al., 2006; Medvecká et al., 2012). The supposed negative impacts of invasive plants upon communities and ecosystems have so far been poorly investigated in urban areas, where invasions are a main issue for ecologists and for urban planners and managers (Maurel et al., 2010).

In this study, we investigated the occurrence of non-native plant species (neophytes) in selected types of anthropogenic habitats in order to determine variability of their occurrence associated with the change in altitude and links of the invading taxa to the monitored biotope types, as well as their links to individual monitored regions. The research was conducted in three regions of South-Western Slovakia.

\section{Studied areas and types of anthropogenic biotopes}

Our research was aimed at ecologically different areas:

Village Velčice (foothill area) is located in the north-western part of the district Zlaté Moravce. The territory belongs to the basin of the river Nitra (Majerčáková, 2002); climatic region is mild, with an average annual temperature of $8{ }^{\circ} \mathrm{C}$. Municipal boundary extends to the top of the highest peak of the mountains, Velký Tríbeč (829 m.a.s.l.) (Lapin et al., 2002). The aver- 
age altitude of the village is a $223 \mathrm{~m}$ a.s.l. Total cadastral area of Velčice represents 3,470.4747 hectares and the number of inhabitants reached is 844 (December 30, 2010). Population density was 24 inhabitants per $\mathrm{km}^{2}$ (Statistical Office of the SR, 2011).

Village Velké Zálužie (upland area) is located in the western part of the district Nitra. The area belongs to the basin of the rivers Váh and Nitra (Majerčáková, 2002); climatic region is warm with mild winters and average annual temperature of $10^{\circ} \mathrm{C}$ (Lapin et al., 2002). Average altitude of the village is 180 m.a.s.l. Total cadastral area of Velké Zálužie is 3,210.3731 hectares, population reached 4,255 people (December 30, 2010). Population density represented 132 inhabitants per $\mathrm{km}^{2}$ (Statistical Office of the SR, 2011).

Village Dubník (lowland area) is located in the central part of the district Nové Zámky. The area belongs to the basin of the river Hron (Majerčáková, 2002); climatic region is warm with long dry summers and short and mild winters. Average annual temperature is between $10-12^{\circ} \mathrm{C}$ (Lapin et al., 2002). Average altitude of the village is 138 m.a.s.l. Total cadastral area is $4,100.6161$ hectares, population reached is 1,724 inhabitants (December 30, 2010). Population density was 42 inhabitants per $\mathrm{km}^{2}$ (Statistical Office of the SR, 2011).

The study monitored the occurrence of non-native plant species (only neophytes were observed-species introduced after AD 1500; Pyšek et al., 2004 for definition) in the following types of anthropogenic biotopes (Ružičková et al., 1996): cemeteries, abandoned and unused fields, roadsides, railways (present only in the lowland), non-native forests, grasslands, banks of flowing waters.

Due to unsatisfactory classification of habitats of gardens and yards according to the available literature (Ružičková et al., 1996; Chytrý et al., 2001; Stanová, Valachovič, 2002), we defined these separately as: Stands with predominance of herbs that were created together with build-up areas. The specific stand contains always only some species, often non-native and exotic, while these species form sometimes their dominant element.

\section{Floristic assessment of the biotopes and data analysis}

Floristic assessment of the biotopes was conducted during the summer of 2011 by the mapping method. Field study included investigation of the occurrence (presence/absence) of non-native plant species observed within boundaries of the villages and identification of anthropogenic habitats. The identification of the non-native plants was based on a list of invasive plant species of Slovakia according to Medvecká et al. (2012). Nine plant species of the list are also included in the Slovak legislation (Ambrosia artemisiifolia, Fallopia $\times$ bohemica, F. japonica, F. sachalinensis, Helianthus tuberosus, Heracleum mantegazzianum, Impatiens glandulifera, Solidago canadensis and S. gigantea) (Proclamation of MESR No. 173/2011). The species nomenclature was stated according to Marhold, Hindák (1998).

Achieved results containing the number of mapped non-native species, the number of invaded anthropogenic habitats and the number areas of non-native species occurrence within each habitat were evaluated by multivariate analysis in statistical program CANOCO 4.5 and CanoDraw for Windows (ter Braak, Šmilauer, 2002). Using ordination procedures, it is possible to find in the entire set of objects those that are similar to each other and differ from others, or find such groups of variables that correlate with each other (Pilko, 2002). Ordination 
techniques help in explaining variation in plant communities (Gauch, 1982). Data analysis was performed by indirect linear model (principal components analysis-PCA). Centering (isstandardisation) of the data was carried out according to the samples.

\section{Results and discussion}

In general, non-native plant species colonise preferably lowland areas, however they occur also in higher areas and occasionally in high altitudes (Chytrý, Pyšek, 2008). Our research confirmed the highest number of invasive neophytes (14) in the lowland area. The same number of invasive neophytes (12) was recorded in upland and foothill area, respectively. List of all mapped non-native plant species with their number of all invaded habitats within each study areas is presented in Table 1.

$\mathrm{T} \mathrm{a} \mathrm{b} \mathrm{le} 1$. The number of invaded habitats by invasive neophytes within the study areas.

\begin{tabular}{|l|c|c|c|}
\hline Study areas & Foothills & Upland & Lowland \\
\hline Invasive neophytes/villages & Velčice & Velké Zálužie & Dubník \\
\hline Ailanthus altissima (Mill.) Swingle & 0 & 63 & 111 \\
\hline Aster novi-belgii (L.) G. L. Nesom & 68 & 10 & 10 \\
\hline Bidens frondosa L. & 79 & 0 & 77 \\
\hline Conyza canadensis (L.) Cronquist & 52 & 103 & 42 \\
\hline Fallopia $\times$ bohemica Chrtek et Chrtková & 2 & 12 & 6 \\
\hline Galinsoga parviflora Cav. & 17 & 54 & 80 \\
\hline Helianthus tuberosus L. & 10 & 32 & 91 \\
\hline Lycium barbarum L. & 20 & 7 & 9 \\
\hline Negundo aceroides Moench. & 0 & 4 & 20 \\
\hline Parthenocissus quinquefolia (L.) Planch & 1 & 26 & 179 \\
\hline Rhus typhina L. & 14 & 130 & 142 \\
\hline Robinia pseudoacacia L. & 51 & 45 & 78 \\
\hline Solidago canadensis L. & 17 & 105 & 25 \\
\hline Stenactis annua (L.) Nees & 31 & 54 & 2 \\
\hline
\end{tabular}

In the foothill area, we recorded absence of two invasive plant species, particularly invasive neophyte Ailanthus altissima, as well as ornamental tree Negundo aceroides. Absence of two herbaceous invasive neophytes Bidens frondosa and Galinsoga parviflora was recorded in the upland area. In all of the mapped areas, the same number of invasive plant species that are contained in the Slovak legislation: Fallopia $\times$ bohemica, Helianthus tuberosus and Solidago canadensis was recorded (Table 1).

Several of the mapped species created extensive stands most often near human settlements and their surroundings occurring on a wide variety of anthropogenic habitats, which 
were characterised by different ecological conditions, different frequency and intensity of disturbances etc. Depending on these factors (as well as the supply of diasporas), the presence of invasive neophytes differed, both in the number of their habitats, as well as dependence on the type of biotope.

The known invasive behaviour from different regions is one of the best predictors in weed risk assessment systems (Daehler et al., 2004). Our study may also provide important information for managers performing preventive and containment measures or eradication actions as well.

\section{Foothill area}

The most commonly invaded anthropogenic habitats of the foothill area were banks of flowing waters (168 sites) and roads (81 sites). According to Rahlao et al. (2010), roads and rivers may be dispersal corridors for invasive alien species that fly and float. These two systems interact at bridge interchanges.

Based on Fig. 1, we can conclude that the habitats with the most typical occurrence of invading plant species in the foothill areas were banks of flowing waters.

Invasive taxa of Bidens frondosa and Parthenocissus quinquefolia occurred only on the banks of streams flowing through the village, especially on the banks of Čerešnový Creek. They can be therefore classified as species with high affinity to this type of semiterrestrial biotope. Habitat linkage of invasive neophyte Aster novi-belgii spreading preferably along water courses was observed, as well.

Along the road, the most frequently detected was the presence of invasive neophytes

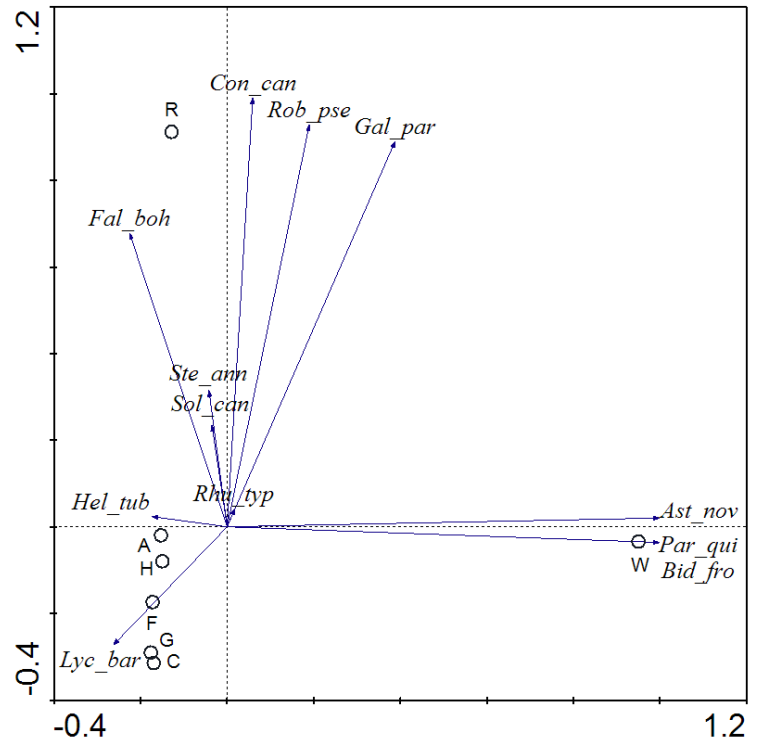

Fig. 1. Habitat linkage of non-native plant species to particular types of anthropogenic habitats in the foothill area evaluated by PCA ordination diagram (A-abandoned and unused fields, C-cemeteries, F-non-native forests, G-grasslands, H-gardens or yards, R-roadsides, W-banks of flowing waters); for explanation of non-native species' acronyms, see Appendix. Conyza canadensis and Robinia pseudoacacia with significant habitat linkage to this type of biotope (Fig. 1). However, it should be highlighted that about $70 \%$ of the cadastral area of Velčice is wooded and the invasive species $R$. pseudoacacia is very common there. The species successfully penetrates also to the native oak-hornbeam forests. Extensive non-native stands with this species as 
dominant can be found in old erosion potholes in deforested area surrounding the village (Eliáś, 1997). Roads were preferably invaded by annual invasive plant Galinsoga parviflora. This weed invaded mainly vegetation of street gutters. It is well adapted to disturbed habitats and it succeeds particularly in moist soils (Damalas, 2008). Disturbance of roadsides is higher compared to interior habitats of the adjacent landscape and significantly explains higher non-native species richness (McIntyre, Lavorel, 1994; Gelbard, Harrison, 2003). Therefore, the roads can be described as a biotope very prone to penetration and expansion of this non-native species. Its affinity was slightly shifted to the banks of flowing waters (Fig. 1). It resulted from the findings of its frequent presence on the banks of streams flowing through the village.

Frequent occurrence of invasive neophytes, was also recorded in the habitats of gardens and yards ( 44 sites) and abandoned areas ( 30 sites). Some of non-native plants that occurred in villages were planted as ornamental plants and they escaped from the cultures, expanded and spread further on abandoned areas in villages, banks of rivers and so on (Kowarik, 2005; Pauková, 2013). Their affinity is therefore shifted to the habitats into which they spread from the starting point of introduction. This phenomenon can be observed, for example in invasive neophytes Solidago canadensis and Helianthus tuberosus that were recorded in gardens and yards but their affinity to roads can be observed as well (Fig. 1).

Some non-native species were observed in several biotopes (e.g. Stenactis annua) with approximately the same number of sites of their occurrence within the biotope. Other species occurred in our records only a few times (e.g. Lycium barbarum, Fallopia $\times$ bohemica). These were often characterised by highly variable or very low habitat linkage and thus it is not possible to determine their direct link to a particular type of anthropogenic habitat

\section{Upland area}

The largest number of sites with the occurrence of invasive neophytes in the upland area represented unused areas (209 sites). If old fields are abandoned and unmanaged, many of them can eventually become forests through the natural process of succession. These abandoned ecosystems are commonly invaded by numerous invasive plant species, which could alter successional dynamics and affect the characteristics of young forests derived from invaded old fields (Kuebbing et al., 2014).

In abandoned sites of the studied upland area, we recorded high habitat linkage of invasive tree species Robinia pseudoacacia, which represented one of the most common tree species in the village and invaded especially abandoned, from the succession point of view, young phytocoenoses. Invasive shrub Lycium barbarum also showed habitat linkage to this type of biotope (Fig. 2).

High habitat linkage to abandoned and unused areas among herbs can be attributed to invasive neophyte Conyza canadensis, which grew especially in barren and nutrient-poor sites, and also to herbaceous species Stenactis annua (Fig. 2). All of the above taxa were also characterised by a closer linkage to the roads and high capability of spreading along these corridors. According to Lippe, Kowarik (2007), many invasive plant species adapted to disturbed sites are also able to grow along roads. 
Biotopes of gardens and yards can be designated as biotopes with the most typical representation of invading plant species in the upland area. The occurrence of all invasive neophytes identified in the upland area was confirmed in this type of biotope, except a non-native tree species, Negundo aceroides. Overall, we found here, penetration of invading plant species in 185 cases.

Significant affinity to this type of biotope was characterised for purposely planted nonnative taxa Fallopia $\times$ bohemica, Rhus typhina, Parthenocissus quinquefolia and Helianthus tuberosus (Fig. 2). The latter invasive taxon invaded the highest number of sites identified in biotopes of gardens and yards (41

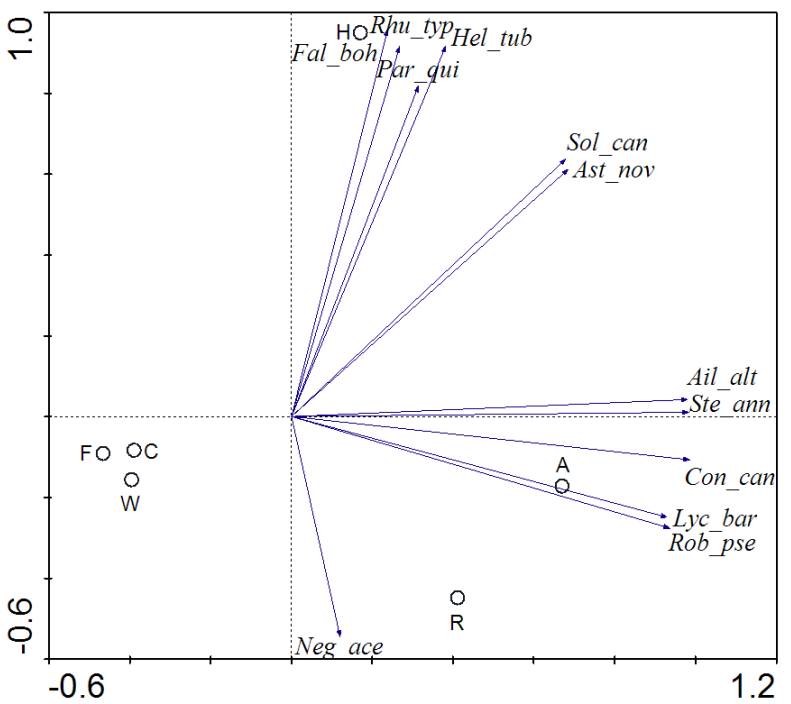

Fig. 2. Habitat linkage of non-native plant species to particular types of anthropogenic habitats in the upland area evaluated by PCA ordination diagram (A-abandoned and unused fields, C-cemeteries, F-nonnative forests, $\mathrm{H}$-gardens or yards, R-roadsides, W-banks of flowing waters); for explanation of non-native species acronyms, see Appendix. sites). Outplanting for ornamental purposes and cultivation as a vegetable, fodder crop or a source of inulin (Kays, Nottingham, 2008) makes this species very attractive for humans and contributes to its introduction into gardens or yards in the vicinity of human settlements. In some cases, Helianthus tuberosus escaped from cultures, spread along roads and invaded abandoned and unused habitats. This phenomenon was observed mainly in two invasive Asteraceae species: Solidago canadensis and Aster novi-belgii, where habitat linkage is significantly shifted towards the abandoned sites (Fig. 2). Plants cultivated in gardens or other ornamental plantations possess no danger to the environment until they remain in cultivation; however, any plant that has escaped from cultivation should not be neglected because this process can be the start of species naturalisation and future invasion (Kowarik, 2003, Pyšek et al., 2004; Dobravolskaite, Gudžinskas, 2011).

Habitats of banks of flowing waters, cemeteries and non-native forests of the upland area, possessed only a random occurrence of non-native species of plants without significant linkage to these habitats.

\section{Lowland area}

Many invasive neophytes of the lowland area were characterised by affinity to several habitat types at the same time, mainly to biotopes of gardens and yards, abandoned and unused areas and also to roads (Fig. 3). 


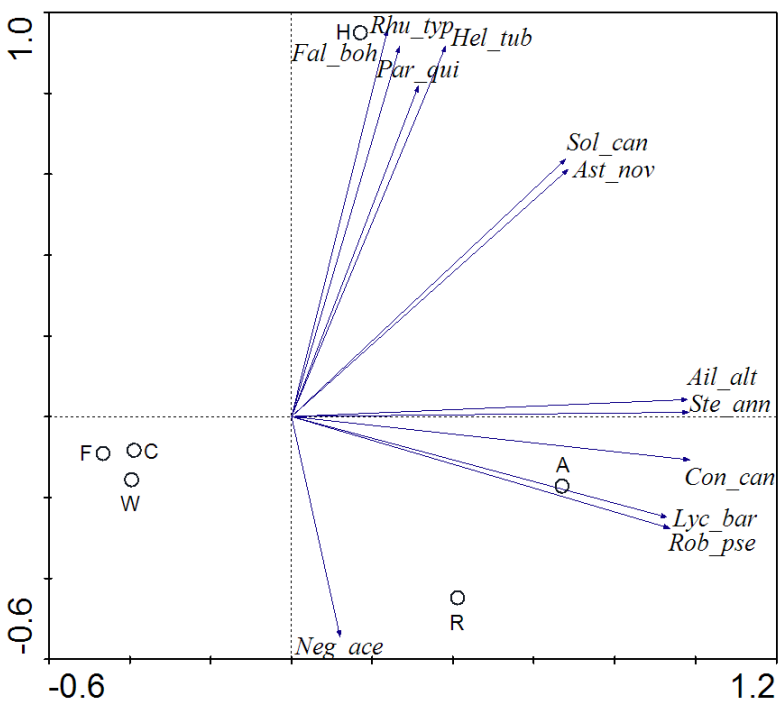

Fig. 3. Habitat linkage of non-native plant species to particular types of anthropogenic habitats in the lowland area evaluated by PCA ordination diagram (A-abandoned and unused fields, C-cemeteries, F-non-native forests, G-grasslands, $\mathrm{H}$-gardens or yards, R-roadsides, T-railways, W-banks of flowing waters); for explanation of non-native species' acronyms, see Appendix.

etrated by invasive woody plants Lycium barbarum and Robinia pseudoacacia (Fig. 3).

A slightly smaller number of invasive neophytes occurrences (270 sites) were recorded in biotopes of gardens and yards. The most common purposely cultivated species with high invasive potential in the village Dubník were Aster novi-belgii, Solidago canadensis, Helianthus tuberosus, Rhus typhina, and also woody liana Parthenocissus quinquefolia, which often decorated house walls. From these cultures, the aggressive invasive neophyte Solidago canadensis escaped the most frequently, penetrating mainly into abandoned habitats (Fig. 3) where it often created extensive monocoenoses. The species was characterised by a high potential to invade abandoned and unused habitats of the studied lowland area (up to 60 sites detected).

Banks of rivers are also very vulnerable to invasion by exotic species (Hood, Naiman, 2000). A typical alien species of the habitats of banks of flowing waters was Bidens frondosa. The species was characterised by high affinity to the bank of the stream Paríž flowing through the village (Fig. 3). It was the most commonly observed in close contact with water surface.

The village Dubník is the only of the observed villages with a railway connection, along which we recorded only the occurrence of non-native woody species, Ailanthus altissima, Lycium barbarum, Negundo aceroides and Robinia pseudoacacia. These species were characterised by only a low affinity to railroads. They favoured spreading along roads or invaded abandoned and from the succession point of view young biotopes. Some studies have explored the relationship between non-native plants and railway corridors (Zika, 1990; Warwick, Wall, 
1998) or frequency of presence of non-native plant species along railways (Hansen, Clevenger, 2005).

\section{Affinity of non-native species to altitudinal gradient}

We recorded a reduction in the total amount of sites with the presence of invasive neophytes in connection to increasing altitude. Invasive neophytes invaded 910 sites within various types of the studied anthropogenic habitats in the lowland area. Compared to the lowland area, about $35 \%$ fewer sites were recorded in the upland area. A further increase in altitude caused a decrease in the number of invaded sites and from the foothill towards the upland area; we recorded about $42 \%$ fewer sites with the occurrence of non-native plant species.

This decreasing along altitudinal gradients depends on several factors, which determine the ability of alien species to spread and invade communities. The spread of a species in a new range is limited by propagule pressure, abiotic factors and biotic interactions with competitors, enemies etc., and all these factors may vary along altitudinal gradients (Dietz, Edwards, 2006; Alexander et al., 2009). An important factor influencing whether or not a non-native plant species becomes invasive is the climate in the area of introduction. To become naturalised in the new range, a species must either be climatically pre-adapted (climate matching), have a high phenotypic plasticity, or be able to adapt genetically, which in the latter case may take many generations (Haider et al., 2010).

The high occurrence of invaded habitats by invasive neophytes not only in the lowland but also the upland area cannot be attributed solely to favourable natural conditions of the areas offering better conditions to thermophilic allochthonous species for their establishment, growth, development and creation of new viable populations. Compared to the foothill area, these are characterised also by a higher rate of settlement (Dubník almost double, Velké Zálužie more than five-fold) and in the case of the village Vel'ké Zálužie, even more favourable location within the transport communication and/or greater traffic intensity. It is these factors that play an important role in terms of transfer of diasporas of non-native species. Similarly, Pyšek (1998) recognised that species' number also increased with the density of human population and with mean of annual temperature and decreased with increasing altitude. Moreover, Medvecká et al. (2014) presume that as long as human influence in higher altitudes does not decrease, the spread of alien species to higher altitudes will continue.

Based on Fig. 4, we can conclude that the foothill area appeared as an area creating the best conditions for establishment, growth, development and creation of new viable populations of invasive neophytes Bidens frondosa and Galinsoga parviflora, which occupied explicitly linear biotopes.

Invasive perennial plant Aster novi-belgii was characterised by affinity to the foothill, as well as the lowland area. It results both from its spontaneous expansion along the riverbanks and occasionally roads in the foothill area (Fig. 1), as well as its intentional cultivation in gardens and yards of the lowland area (Fig. 3), where it can be described as the most commonly grown ornamental invasive plant species (70 sites). Based on our observation, A. novi-belgii can be described as a highly variable species, tolerant to wide range of factors limiting spread of species along elevation gradient. 


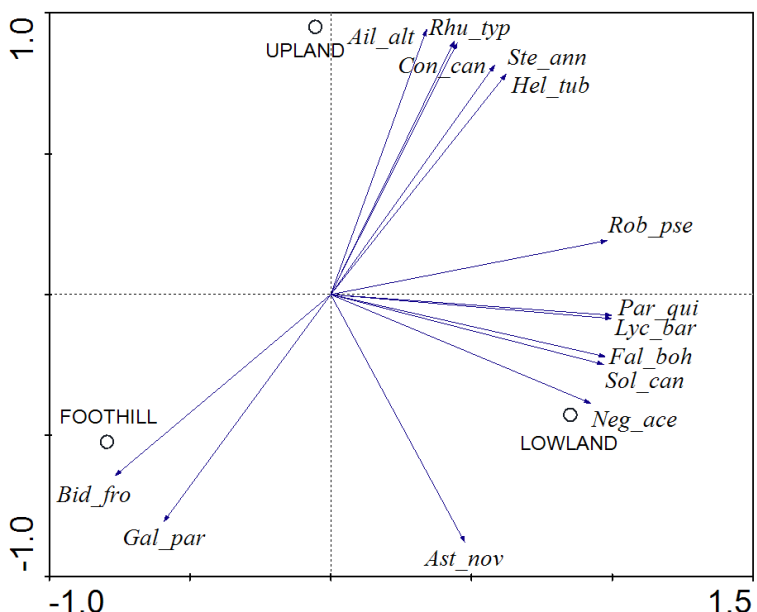

Fig. 4. Affinity of non-native plant species to particular types of the studied areas evaluated by PCA ordination diagram (for explanation of non-native species acronyms, see Appendix).

In the upland and lowland areas, we noted a wider range of species showing a high affinity to the conditions of these areas. Invasive neophytes $A i-$ lanthus altissima and Conyza canadensis penetrating mainly to abandoned and unused sites, but also Rhus typhina preferably planted by growers (Fig. 2 ), were characterised by affinity to the upland area. The lowland area was characterised by the occurrence of invasive neophytes Negundo aceroides, Solidago canadensis and also hybrid taxon Fallopia $\times$ bohemica with narrower habitat linkage to the abandoned and unused biotopes (Fig. 3). However, some species typical for upland area were characterised by a high ability to invade anthropogenic biotopes of the lowland area (Stenactis annua, Helianthus tuberosus) and vice versa (Lycium barbarum, Parthenocissus quinquefolia). This phenomenon is observable best in invasive tree species Robinia pseudoacacia (Fig. 4), which invaded mostly anthropogenic biotopes in both lowland and upland areas.

\section{Conclusion}

Altitude was the important factor determining variability of invasive neophytes' occurrence. The highest number of invasive neophytes (14) was recorded in the lowland area. The foothill and upland areas had the same number of invasive neophytes (12). All invasive species present in the foothill and upland were observed in the lowland as well. Some typical upland species often invaded to anthropogenic habitats of the lowland and vice versa. The total amount of habitats with invasive neophytes' occurrence showed a linear increase along the altitudinal gradient, with the lowest amount of these habitats at high altitude and the highest amount at low altitude. Areas with higher rates of settlement and suitable transport connection provide more favourable conditions for penetration of invasive neophytes. The number of invaded habitats increased with increase of average temperature.

In the foothill area, the most important dispersal corridors for invasive neophytes were banks of flowing waters and roadsides. High affinity to the riverbanks flowing through the village is characterised for invasive neophytes Bidens frondosa and Parthenocissus quinquefolia. There was also presence of affinity between invasive neophyte Aster novi-belgii and banks of flowing waters. A. novi-belgii can be described as very variable species tolerant to 
wide range of factors limiting the spread of species along the elevation gradient. Invasive neophytes Conyza canadensis and Robinia pseudoacacia showed their habitat inclination to roadsides in the foothill area. High affinity to the foothill area was characterised preferentially by invasive herbs Bidens frondosa and Galinsoga parviflora.

In the upland territory, the most susceptible biotopes for the penetration of invading species were abandoned and unused fields. High habitat linkage to these areas was characterised by invasive woody species Robinia pseudoacacia, Lycium barbarum and invasive herbs Conyza canadensis and Stenactis annua. Many invasive plant species adapted to abandoned biotopes of the upland area were also able to grow along roads, and vice versa. Nonnative taxons Fallopia $\times$ bohemica, Rhus typhina, Parthenocissus quinquefolia and Helianthus tuberosus were characterised by their habitat affinity to biotopes of gardens and yards. Increased affinity to the upland area was observed in invasive neophytes Ailanthus altissima, Conyza canadensis and Rhus typhina.

In the lowland territory, the most frequently invaded biotopes were roadsides. Higher affinity to them was showed by invasive plants Lycium barbarum and Robinia pseudoacacia.

Abandoned and unused biotopes of the lowland area created conditions for many typical invasive neophytes occurring along roads and biotopes of gardens and yards. There was an enhanced affinity found between invasive neophyte Ailanthus altissima and abandoned biotopes. Non-native herb species Bidens frondosa was characterised by high affinity to the riverbanks flowing through the village. Railroads provide habitats and means of dispersal for woody neophytes. Closer affinity to the lowland area was characterised by invasive neophytes Negundo aceroides, Solidago canadensis and also hybrid taxon Fallopia $\times$ bohemica.

Gardens and yards were an important source of alien species in all observed areas and significantly contributed to the dispersal especially into neighbouring abandoned habitats. Many of the studied biotopes possessed only a random occurrence of invasive neophytes without significant linkage to a particular habitat type.

Acknowledgements

Our sincere thanks to Dr. Martin Hauptvogl for assisting with the language corrections of this paper.

\section{Appendix}

Explanation of non-native species acronyms used in ordination diagrams: Ast_nov-Aster novi-belgii; Ail_alt-Ailanthus altissima; Bid_fro-Bidens frondosa; Con_can-Conyza canadensis; Fal_boh-Fallopia $\times$ bohemica; Gal_par-Galinsoga parviflora; Hel_tub-Helianthus tuberosus; Lyc_bar-Lycium barbarum; Neg_ace-Negundo aceroides; Par_quiParthenocissus quinquefolia; Rhu_typ-Rhus typhina; Rob_pse-Robinia pseudoacacia; Sol_can-Solidago canadensis; Ste_ann-Stenactis annua

\section{References}

Alexander, J.M., Naylor, B., Poll, M., Edwards, P.J. \& Dietz H. (2009). Plant invasions along mountain roads: the altitudinal amplitude of alien Asteraceae forbs in their native and introduced ranges. Ecography, 32(2), 334-344. DOI: $10.1111 /$ j.1600-0587.2008.05605.x.

Arévalo, J.R., Delgado, J.D., Otto, R., Naranjo, A., Salas, M. \& Fernández-Palacios J.M. (2005). Distribution of alien 
vs. native plant species in roadside communities along an altitudinal gradient in Tenerife and Gran Canaria (Canary Islands). Perspect. Plant Ecol. Evol. Syst., 7(3), 185-202. DOI: 10.1016/j.ppees.2005.09.003.

Becker, T., Dietz, H., Billeter, R., Buschmann, H. \& Edwards P.J. (2005). Altitudinal distribution of alien plant species in the Swiss Alps. Perspect. Plant Ecol. Evol. Syst., 7(3), 173-183. DOI: 10.1016/j.ppees.2005.09.006.

Christen, D. \& Matlack G. (2006). The role of roadsides in plant invasions: a demographic approach. Conserv. Biol., 20(2), 385-391. DOI: 10.1111/j.1523-1739.2006.00315.x.

Chytrý, M., Kučera, T. \& Kočí M. (2001). Catalogue of biotopes of the Czech Republic (in Czech). Praha: Agentura ochrany př́rody a krajiny ČR.

Chytrý, M. \& Pyšek P. (2008). Invasions by alien species in plant communities (in Czech). Zprávy České Botanické Společnosti, Materiály, 23, 17-40.

Daehler, C.C., Denslow, J.S., Ansari, S. \& Kuo H.C. (2004). A risk-assessment system for screening out invasive pest plants from Hawaii and other Pacific Islands. Conserv. Biol., 18(2), 360-368. DOI: 10.1111/j.15231739.2004.00066.x.

Damalas, Ch.A. (2008). Distribution, biology, and agricultural importance of Galinsoga parviflora (Asteraceae). Weed Biol. Manag., 8(3), 147-153. DOI: 10.1111/j.1445-6664.2008.00290.x.

Deutschewitz, K., Lausch, A., Kühn, I. \& Klotz S. (2003). Native and alien plant species richness in relation to spatial heterogeneity on a regional scale in Germany. Glob. Ecol. Biogeogr., 12(4), 299-311. DOI: 10.1046/j.1466822X.2003.00025.x.

Dickens, S.M., Gerhardt, F. \& Collinge S.K. (2005). Recreational portage trails as corridors facilitating non-native plant invasions of the Boundary Waters Canoe Area Wilderness (U.S.A.). Conserv. Biol., 19(5), 1653-1657. DOI: $10.1111 /$ j.1523-1739.2005.004285.x.

Dietz, H. \& Edwards P.J. (2006). Recognition that causal processes change during plant invasion helps explain conflicts in evidence. Ecology, 87(6), 1359-1367. DOI: 10.1890/0012-9658(2006)87[1359:RTCPCD]2.0.CO;2.

Dobravolskaitè, R. \& Gudžinskas Z. (2011). Alien plant invasion to forest in the vicinity of communal gardens. Botanica Lithuanica, 17(2/3), 73-84.

Eliáš, P. (1997). Natural condition (in Slovak). In M. Eliáš (ed.), Velčice: Z dejín, prírody a kultúry obce (pp. 58-74). Velčice: Obecný úrad.

Eliáś, P. (2001). Biotic invasions and invasive organisms (in Slovak). Životné Prostredie, 35(2), 61-66.

Gauch, Jr., H.G. (1982). Multivariate analysis in community ecology. Cambridge: Cambridge University Press.

Gelbard, J.L. \& Harrison S. (2003). Roadless habitats as refuges for native grasslands: Interactions with soil, aspect, and grazing. Ecol. Appl., 13(2), 404-415. DOI: 10.1890/1051-0761(2003)013[0404:RHARFN]2.0.CO;2.

Haider, S., Alexander, J., Dietz, H., Trepl, L., Edwards, P.J. \& Kueffer Ch. (2010). The role of bioclimatic origin, residence time and habitat context in shaping non-native plant distributions along an altitudinal gradient. Biol. Invasions, 12(12), 4003-4018. DOI: 10.1007/s10530-010-9815-7.

Hansen, M.J. \& Clevenger A.P. (2005). The influence of disturbance and habitat on the presence of non-native plant species along transport corridors. Biol. Conserv., 125(2), 249-259. DOI: 10.1016/j.biocon.2005.03.024.

Hood, W.G. \& Naiman R.J. (2000). Vulnerability of riparian zones to invasion by exotic vascular plants. Plant Ecol., 148(1), 105-114. DOI: 10.1023/A:1009800327334.

Kays, S.J. \& Nottingham S.F. (2008). Biology and chemistry of Jerusalem Artichoke: Helianthus tuberosus L. Boca Raton: CRC Press.

Körner, Ch. (2003). Alpine plant life: functional plant ecology of high mountain ecosystems. Berlin: Springer.

Kowarik, I. (2003). Human agency in biological invasions: secondary releases foster naturalization and population expansion of alien plant species. Biol. Invasions, 5(4), 293-312. DOI: 10.1023/B:BINV.0000005574.15074.66.

Kowarik, I. (2005). Urban ornamentals escaped from cultivation. In J. Gressel (Ed.), Crop ferality and volunteerism (pp. 97-121). Boca Raton: CRC Press.

Kuebbing, S.E., Souza, L. \& Sanders N.J. (2014). Effects of co-occurring non-native invasive plant species on oldfield succession. For. Ecol. Manag., 324, 196-204. http://dx.doi.org/10.1016/j.foreco.2013.10.031

Lapin, M., Faško, P., Melo, M., Štastný, P. \& Tomlain J. (2002). Climate (in Slovak). In Atlas SR. Bratislava: MŽP SR, Banská Bystrica: SAŽP.

Lippe, M. von der \& Kowarik I. (2007). Long-distance dispersal of plants by vehicles as a driver of plant invasions. Conserv. Biol., 21(4), 986-996. DOI: 10.1111/j.1523-1739.2007.00722.x.

Lososová, Z., Chytrý, M., Kühn, I., Hájek, O., Horáková, V., Pyšek, P. \& Tichý L. (2006). Patterns of plant traits in annual vegetation of man-made habitats in central Europe. Perspect. Plant Ecol. Evol. Syst., 8(2), 69-81. DOI: 10.1016/j.ppees.2006.07.001. 
Majerčáková, O. (2002). Waters (in Slovak). In Atlas SR (pp. 102). Bratislava: MŽP SR, Banská Bystrica: SAŽP.

Maskell, L.C., Firbank, L.G., Thompson, K., Bullock, J.M. \& Smart S.M. (2006). Interactions between non-native plant species and the floristic composition of common habitats. J. Ecol., 94(6), 1052-1060. DOI: 10.1111/j.13652745.2006.01172.x.

Marhold, K. \& Hindák F. (Eds.) (1998). Checklist of non-vascular and vascular plants of Slovakia (in Slovak). Bratislava: VEDA.

Maurel, N., Salmon, S., Ponge, J.F., Machon, N., Moret, J. \& Muratet A. (2010). Does the invasive species Reynoutria japonica have an impact on soil and flora in urban wastelands? Biol. Invasions, 12(6), 1709-1719. DOI: 10.1007/ s10530-009-9583-4.

McDougall, K.L., Morgan, J.W., Walsh, N.G. \& Williams R.J. (2005). Plant invasions in treeless vegetation of the Australian Alps. Perspect. Plant Ecol. Evol. Syst., 7(3), 159-171. DOI: 10.1016/j.ppees.2005.09.001.

McIntyre, S. \& Lavorel S. (1994). Predicting richness of native, rare, and exotic plants in response to habitat and disturbance variables across a variegated landscape. Conserv. Biol., 8(2), 521-531. DOI: 10.1046/j.15231739.1994.08020521.x.

McKinney, M.L. (2006). Urbanization as a major cause of biotic homogenization. Biol. Conserv., 127(3), $247-260$. DOI: $10.1016 /$ j.biocon.2005.09.005.

Medvecká, J., Kliment, J., Májeková, J., Halada, L., Zaliberová, M., Gojdičová, E., Feráková, V. \& Jarolímek I. (2012). Inventory of the alien flora of Slovakia. Preslia, 84(2), 257-309.

Medvecká, J., Jarolímek, I., Senko, D. \& Svitok M. (2014). Fifty years of plant invasion dynamics in Slovakia along a 2,500 m altitudinal gradient. Biol. Invasions, 16(8), 1627-1638. DOI: 10.1007/s10530-013-0596-7.

Parks, C.G., Radosevich, S.R., Endress, B.A., Naylor, B.J., Anzinger, D., Rew, L.J., Maxwell, B.D. \& Dwire K.A. (2005). Natural and land-use history of the Northwest mountain ecoregions (USA) in relation to patterns of plant invasions. Perspect. Plant Ecol. Evol. Syst., 7(3), 137-158. DOI: 10.1016/j.ppees.2005.09.007.

Pauchard, A. \& Alaback P.B. (2004). Influence of elevation, land use, and landscape context on patterns of alien plant invasions along roadsides in protected areas of South-Central Chile. Conserv. Biol., 18(1), 238-248. DOI: 10.1111/j.1523-1739.2004.00300.x.

Pauková, Ž. (2013). Invasive plant species in the three microregions of Nitra region, South-West Slovakia. Ekológia (Bratislava), 32(2), 262-266. DOI: 10.2478/eko-2013-0022.

Pilko, M. (2002). Selected methodological approaches to the study of vegetation. In Acta Environmentalica Universitatis Comenianae, 11(Suppl.), 159-170.

Proclamation of Ministry of Environment of the Slovak Republic No. 173/2011 Available at: http://www.zbierka.sk/ sk/predpisy/173-2011-z-z.p-34130.pdf

Pyšek, P. (1998). Alien and native species in Central European urban floras: a quantitative comparison. J. Biogeogr., 25(1), 155-163. DOI: 10.1046/j.1365-2699.1998.251177.x.

Pyšek, P., Richardson, D.M., Rejmánek, M., Webster, G., Williamson, M. \& Kirschner J. (2004). Alien plants in checklists and floras towards better communication between taxonomists and ecologists. Taxon, 53(1), 131-143.

Rahlao, S.J., Milton, S.J., Esler, K.J. \& Barnard P. (2010). The distribution of invasive Pennisetum setaceum along roadsides in western South Africa: the role of corridor interchanges. Weed Res., 50(6), 537-543. DOI: 10.1111/j.1365-3180.2010.00801.x.

Ružičková, H., Halada, L., Jedlička, L. \& Kalivodová E. (Eds.) (1996). Biotopes of Slovakia: Handbook to mapping and register of biotopes (in Slovak). Bratislava: ÚKE SAV.

Stanová, V. \& Valachovič M. (Eds.) (2002). Catalogue of biotopes of Slovakia (in Slovak). Bratislava: DAPHNE - Inštitút aplikovanej ekológie.

Statistical Office of the SR (2011). Urban and municipal statistics. MOS Information System (online) (cit. 2012-0301). Available at: http://app.statistics.sk/mosmis/eng/run.html

Ter Braak, C.J.F. \& Šmilauer P. (2002). Reference manual and CanoDraw for Windows user's guide : Software for canonical community ordination (version 4,5). Ithaca: Microcomupter Power.

Warwick, S.I. \& Wall D.A. (1998). The biology of Canadian weeds. 108. Erucastrum gallicum (Willd.) O.E. Schulz. Can. J. Plant Sci., 78(1), 155-165.

Zika, P.F. (1990). Range expansions of some grasses in Vermont, USA. Rhodora, 92(870), 80-89. 